\title{
SEMAI: Sembilan Nilai Anti Korupsi dalam Pendidikan Anak Usia Dini
}

\section{Fira Mubayyinah}

STAI Al Hikmah Tuban

Email: firamubayyinah@gmail.com

\begin{abstract}
Corruption is a word that almost every day appears in the media both print and electronic media. Corruption nowadays is so familiar to our ears both for adults, teenagers, even children on elementary school they have often heard and read the word corruption. Although the moment is not necessarily all understand the meaning of corruption. Corruption is an extraordinary crime, so its eradication must also done with extraordinary efforts as well. One of the efforts to minimize the generation that has corrupt behavior then is extraordinary prevention efforts early. One way to do that is to conduct the character based education with anti corruptive behavior. This becomes very important as an effort to prevent corrupt behavior from the "bottom up" way, and with still continue the "top down" way. Formulating some learning model with high integrity value content, urged to be done with creativity to put the blue print of character in children that full with moral and spiritual values.
\end{abstract}

Keywords: values, anti corruption, early childhood education 


\section{PENDAHULUAN}

Istilah "pendidikan sejak dini" digunakan untuk menyebut masa pendidikan paling awal yang dianggap sebagai masa dimana sesorang belum lahir atau masih dalam usia kandungan. Sedangkan "usia dini" yang biasa dikenal dengan istilah golden age adalah usia dimana anak berada pada rentang usia 0 sampai dengan 6 tahun (undang-undang SISDIKNAS tahun 2003), dan didefinisikan pula sebagai kelompok anak yang berada dalam proses pertumbuhan dan perkembangan yang unik. Masa ini adalah masa dimana paling tepat untuk menumbuhkan nilai-nilai kebaikan dalam mengembangkan karakter baik dalam aspek agama, intelektual, sosial, emosional, moral dan spiritual yang dapat diberikan sejak anak dalam kandungan lewat prilaku ibunya.Pendidikan yang diberikan pada anak sejak dini diyakini mampu menjadi bekal pondasi yang kuat kedepannya bagi si anak. Oleh karena itu, pendidikan harus diberikan dengan tujuan yang jelas, yang bisa mengembangkan nilai-nilai kebaikan sebagaimana tersebut diatas. Pendidikan yang diberikan baik secara formal maupun informal diharapkan mampu menjadi pondasi dalam pembentukan moral anak didik.

Pendidikan anti korupsi merupakan salah satu bagian yang penting dalam pembentukan karakter anak yang memiliki integritas tinggi. Hal ini sesuai dengan norma yang ada di UUD 1945 dan UU No. 20 tahun 2003 tentang Sistem Pendidikan Nasional. Jika sekolah sudah memberikan pendidikan anti korupsi sebagai salah satu materi penting untuk diberikan maka sekolah akan menjadi tempat anak didik dalam membiasakan diri untuk memiliki nilai-nilai anti korupsi. Sekolah tidak hanya sebagai tempat yang melahirkan generasi intelektual tingggi, tapi juga akan melahirkan generasi yang memiliki nilai integritas moral yang tinggi, hal ini merupakan upaya preventif yang nyata dalam melakukan pencegahan perilaku koruptif yang berpotensi menjadi pidana korupsi kelak dikemudian hari.

Doktrin anti korupsi yang telah dikenalkan oleh Komisi Pemberantasan Korupsi (KPK) disebut dengan SEMAI (Sembilan Nilai) kehidupan. Nilai-nilai ini dirumuskan dari nilainilai yang diyakini sebagai nilai-nilai kehidupan yang harus diamalkan agar setiap pribadi memiliki prilaku anti koruptif. Berita tentang maraknya kepala daerah, anggota dewan yang terkena Operasi Tangkap Tangan (OTT) oleh Komisi Pemberantasan Korupsi adalah merupakan salah satu kegagalan dalam upaya men stop produk koruptor dari rumah, 
sekaligus menjadi tantangan besar buat kita semua baik dari kalangan pendidik atau orang tua. Permasalah korupsi tidak bisa habis hanya dengan penindakan yang dilakukan oleh Aparat Penegak Hukum (APH) saja. Jauh lebih penting dalam menyelesaikan masalah korupsi adalah upaya untuk melakukan pencegahan dari prilaku koruptif itu sendiri yang harus dimiliki oleh setiap individu. Keterlibatan diri kita untuk, memiliki tanggung jawab dan peranan, penting dalam menyiapkan generasi yang akan datang, sebagai generasi yang berintegritas danmenjadi rumah sebagai tempat pertama yang mampu menstop produksikoruptor sejak dini. Benih perilaku koruptif bisa dicegah sejak dini dengan mengajarkan dan memberikan tauladan kepada anak-anak lewat pendidikan berbasis keluarga. Benih prilaku koruptif yang terus dibiarkan memiliki potensi menjadi prilaku pidana korupsi dikemudian hari.

\section{PEMBAHASAN}

\section{Nilai Anti Korupsi}

Anti korupsi adalah sebuah upaya untuk melakukan pencegahan perbuatan korupsi dengan berbagai upaya untuk meningkatkan kesadaran individu supaya tidak melakukan perbuatan korupsi, sekaligus merupakan upaya perbaikan moral Sumber Daya Manusia. Dalam undang-undang pidana korupsi, nomor 31 tahun 1999 Jo Undang-undang No. 20 tahun 2001, dalam Bab II Pasal 2 disebutkan bahwa, korupsi adalah : "setiap orang yang secara melawan hukum melakukan perbuatan memperkaya diri sendiri atau orang lain atau suatu koorporasi yang dapat merugikan keuangan Negara atau perekonomian Negara". Bahwa siapapun memiliki potensi untuk melakukan perbuatan korupsi, pelaku korupsi tidak mengenal jenis kelamin atau usia dan pelakasanaan kejahatan korupsi selalu dilakukan dengan perencanaan yang matang dan sistematis, tidak ada satupun perbuatan korupsi yang dilakukan dengan tiba-tiba seperti kejahatan pidana yang lainnya.

Masih terekam baik di ingatan kita, beberapa waktu yang lalu Komisi Pemberantasan Korupsi (KPK), menyidangkan perkara korupsi yang pelakunya adalah bapak dan anaknya, mereka secara bersama-sama melakukan perbuatan korupsi, tentu hal ini menjadi kisah nyata yang paling menyedihkan. Orang tua yang seharusnya menjadi tauladan kepada anak-anak nya, namun yang terjadi orang tua melibatkan anaknya untuk secara bersama-sama melakukan permufakatan kejahatan 
korupsi.Tanpa disadari bahwa perbuatan tersebut adalah salah satu bentuk pengkaderan dalam perbuatan pidana korupsi. Banyaknya kasus-kasus yang muncul saat ini harus mampu menjadi cambukan bagi kita untuk lebih giat dan bekerja keras dalam melakukan pendidikan anti korupsi kepada seluruh elemen masyarakat. Karena kita adalah korban kejahatan korupsi yang telah dilakukan oleh para koruptor. Secara materiil uang korupsi yang seharusnya dapat digunakan untuk kepentingan pembangunan ekonomi, pendidikan, kesehatan dan kesejahteraan rakyat, berakibat pada jauhnya harapan itu dapat terwujud. Karena uang itu masuk dikantong para koruptor.

Adapun Bentuk-bentuk pidana korupsi antara lain :

1. Merugikan keuangan Negara

2. Suap

3. Pemerasan

4. Penggelapan dalam jabatan

5. Benturan kepentingan

6. Gratifikasi

7. Tindak pidana pencucian uang dan

Permasalahan korupsi dari hari ke hari semakin meningkat, meskipun ancaman hukuman bagi para koruptor sangat tingggi, namun hal ini tidak cukup ditakuti. Bahkan masalah korupsi ini menjadi masalah serius yang dirasakan oleh setiap Negara, meskipunNegara ini memiliki agama, moral, budaya dan kebiasaan-kebiasan yang baik dan berbasis anti korupsi. Salah satu upaya untuk menekan tingginya angka korupsi adalah dengan melakukan pencegahan, upaya pencegahan ini harus dilakukan sedini mungkin kepada siapapun, salah satu isu penting yang harus mendapatkan perhatian besar adalah dengan memberikan pendidikan anti korupsi kepada masyarakat sejak sedini mungkin.

Istilah nilai banyak berhubungan dengan istilah moral dan etika. Ketika nilai dipisahkan dengan moral, maka arti nilai tidak dipengaruhi oleh moral, yakni tetap pada arti awalnya sebagai suatu keyakinan yang mana seseorang bertindak atas dasar pilihannya. Moral sangat erat kaitannya dengan tanggung jawab sosial yang teruji secara langsung. Tidak seperti halnya nilai, moral menuntut adanya keharusan diakui dan direalisasikan dalam tatanan masyarakat. (Hidayati, 2008). Sedangkan kaitannya dengan Etika, Ahmad Amin (1988) mendefinisikan etika sebagai ilmu yang menjelaskan arti baik-buruk, tindakan yang harus dilakukan manusia terhadap manusia lain, tujuan 
yang harus dicapai, dan jalan yang harus ditempuh. Maka jelas bahwa nilai merupakan tema abstrak dalam kajian etika.

Dalam penelitian tentang Transinternalisasi Nilai yang dilakukan oleh Hidayati (2008), disebutkan bahwa menurut Azwar, nilai disandingkan dengan istilah opini dalam kaitannnya dengan sikap individu. Opini merupakan pernyataan sikap yang sangat spesifik atau sikap dalam artian yang lebih sempit. Opini terbentuk didasari oleh sikap yang sudah mapan akan tetapi opini lebih bersifat situasional dan temporer. Sedangkan nilai merupakan disposisi yang lebih luas dan sifatnya lebih mendasar. Nilai berakar lebih dalam dan karenanya lebih stabil dibandingkan dengan sikap individu. Nilai dianggap sebagai bagian dari kepribadian individu yang dapat mewarnai kepribadian kelompok. Jadi, nilai lebih bersifat mendasar dan stabil sebagai bagian dari ciri kepribadian, sikap bersifat evaluatif dan berakar pada nilai yang dianut dan terbentuk dalam kaitannya dengan suatu obyek.

Dalam teori sikap Katz (Azwar, 1995), nilai ditempatkan pada posisi sebagai salah satu fungsi sikap bagi individu. Menurut Katz, fungsi sikap bagi individu dapat dibagi menjadi empat, yaitu (1) Sikap sebagai fungsi instrumental, fungsi penyesuaian, atau fungsi manfaat. Fungsi ini menyatakan bahwa individu dengan sikapnya berusaha untuk memaksimalkan hal-hal yang diinginkan dan meminimalkan hal-hal yang tidak diinginkan. (2) Sikap sebagai fungsi pertahanan ego. Dalam hal ini sikap merefleksikan problem kepribadian yang tidak terselesaikan. (3) Sikap sebagai fungsi pengetahuan. Dalam hal ini sikap berfungsi sebagai suatu skema, yaitu suatu cara strukturisasi agar dunia di sekitar tampak logis dan masuk akal. Dan (4) Sikap sebagai fungsi pernyataan nilai. Nilai dalam hal ini diartikan sebagai konsep dasar mengenai apa yang dipandang sebagai baik dan diinginkan. Sikap kemudian digunakan sebagai sarana ekspresi nilai sentral dalam diri individu. Dengan fungsi ini seseorang seringkali mengembangkan sikap tertentu untuk memperoleh kepuasan dalam menyatakan nilai yang dianutnya yang sesuai dengan penilaian pribadi dan konsep dirinya.

Mengajarkan nilai-nilai anti korupsi dapat dimulai dengan mengenalkan pada anak mengenai prilaku baik atau buruk, perilaku yang benar dan salah, prilaku yang sesuai atau tidak sesuai dengan norma, ini akan memberikan pengalaman yang baik pada anak dan akan dijadikan pondasi dalam bertingkah laku oleh anak tersebut. Jika penanaman nilai-nilai anti korupsi 
ini gagal dilakukan sejak dari rumah, maka generasi korupsi sepanjang masa akan terus ada dan kebiasaan buruk ini akan terus tumbuh di masyarakat kita. Albert Bandura, seorang tokoh Psikologi yang hidup pada tahun 1925 mengenalkan kepada kita teori learning by modeling, yaitu bagaimana membangun karakter anak yang baik dengan cara memberikan tauladan secara terus menerus baik di rumah maupun di sekolah dan lingkungan kehidupan yang lain.

\section{"SEMAl" Sebagai Doktrin Anti Korupsi}

Masalah korupsi di Indonesia dapat dibilang sudah menggurita dan menular, seperti virus yang dapat ditularkan, kenapa demikian? Beberapa prilaku koruptif yang sering diceritakan oleh satu orang pada orang lain, contohnya dengan tanpa memiliki rasa malu untuk bercerita kepada orang lain atas keberhasilan yang telah dilakukan memberikan tips kepada petugas oknum polisi yang telah menilang kendaraan dan diselesaikan dengan memberikan sejumlah uang yang telah disepakati. Cerita yang diberikan ini menjadi virus orang lain jika dikemudian hari orang lain mengalami hal yang sama akan memilih mengambil solusi yang pernah di dengarnya begitu seterusnya.

SEMAI (Sembilan Nilai), dikenalkan oleh Lembaga Komisi Pemberantasan Korupsi (KPK), sebagai nilai moral yang ampuh dalam memberikan doktrin prilaku anti koruptif. Meskipun saat ini sedang dilakukan pengkajian ulang terhadap Sembilan nilai ini oleh KPK, namun SEMAI ini masih dianggap sangat relevan sebagai nilai doktrin anti korupsi.

Sembilan Nilai kehidupan yang mengajarkan kepada anak tentang nilai moral yang diharapkan akan mampu menumbuh kembangkan sikap atau prilaku sejak dini dengan contoh prilaku sehari-hari yang sering mereka jumpai setiap harinya. Sembilan nilai tersebut adalah: jujur, peduli, mandiri, tanggung jawab, kerjasama, sederhana, kerja keras, berani dan adil, atau agar lebih mudah diingat, nilai-nilai tersebut dirumuskan dalam sebuah kalimat “JUPE TANGKER MANDI SEBEDIL”.

\section{Jujur}

Kata jujur dalam Kamus Besar Bahasa Indonesia (KBBI) berarti: lurus hati; tidak berbohong (bekata apa adanya, tidak curang, mengikuti aturan, tulus dan ikhlas. Dalam rentan waktu tahun 
2012 - 2013 dalam survey yang dilakukan oleh Komisi Pemberantasan Korupsi di Jogjakarta dan Solo, bahwa ternyata hanya sekitar $4 \%$ orang tua yang mengajarkan tentang kejujuran kepada anaknya. Kejujuran yang dimaksaud disini bukan kejujuran dalam arti definisi kejujuran sebagaimana yang dimaksud dalam kamus KBBI, namun lebih pada bagaimana kejujuran tersebut dipraktekkan dalam kehidupan sehari-hari oleh orang tua. Suatu misal, tidak jarang orang tua meminta anaknya untuk menjawab tamu yang tidak dikehendaki kedatanganya dengan menyampaikan bahwa orang tua tidak sedang dalam rumah. Ini adalah bentuk ketidak jujuran yang sedang diajarkan kepada anak sekaligus memberikan contoh perbuatan yang curang.

Bila kita percaya bahwa perilaku korupsi adalah evlolusi dari prilaku koruptif atas hal-hal yang kecil dan dianggap sepele, maka fakta ini adalah salah satu bukti yang menghawatirkan. Lalu bagaiman cara mencegahnya? Memberikan tauladan dan membiasakan anak sejak dini untuk mengatakan segala sesuatu yang terjadi sesuai dengan apa yang mereka lakukan atau ketahui. Kebiasan-kebiasan kecil yang mereka lakukan secara terus menerus akan mampu membentuk karakter anak secara kuat. Output sikap jujur yang dimiliki akan membuahkan hasil manusia yang memiliki kepribadian yang selalu berkata benar dan tidak bohong.

\section{Peduli}

Dalam Kamus Besar Bahasa Indonesia (KBBI) peduli diartikan: mengindahkan; memperhatikan; menghiraukan. Contoh bentuk kepedulian yang bisa diberikan kepada anak adalah mengajak anak atau seluruh anggota keluarga memperhatikan apa yang terjadi di lingkungan sekitar terdekatnya, hal ini diyakini mampu mengasah sekaligus merangsang kepekaan anak terhadap lingkungan sekitar. Misalnya bagaimana orang tua memberikan contoh untuk berani menolak pemberian tamu yang datang, yang diyakini bahwa tamu tersebut memiliki maksud dan tujuan tertentu. Misalnya ketika seorang ibu peka dan mau menanyakan kepada suaminya yang menerima oleh-oleh berupa barang mewah dari rekanan suaminya yang patut diduga ketidakwajaranya dalam memberikan sesuatu itu, begitu juga sebaliknya jika isteri yang menerima. Tauladan-tauladan yang demikian ini akan menempel di memori anak dan memberikan pondasi yang kuat kelak anak sebagai genarasi yang tajam mengenal perbuatan yang boleh dan perbuatan 
yang tidak boleh atau perbuatan yang baik atau tidak baik, yang berpotensi menjadi korupsi.

\section{Mandiri \& Disiplin}

Mandiri diartikan sebagai sikap dalam keadaan dapat berdiiri sendiri; tidak bergantung pada orang lain: sejak kecil ia sudah biasa, sehingga bebas dari ketergantungan pada orang lain. Wujud kemandirian yang bisa diajarkan mendorong anak untuk menyelesaikan tugas dan kewajibanya sendiri tanpa harus menunggu adanya bantuan terlebih dahulu yang diberikan. Disiplin diartikan sebagai sikap yang patuh, tunduk, taat pada peraturan dan tata tertib yang berlaku. Peraturan dibuat untuk mewujudkan keteraturan.

\section{Tanggung Jawab}

Tanggung jawab berarti keadaan wajib menanggung segala sesuatu (kalau terjadi apa-apa boleh dituntut, dipersalahkan, diperkarakan, dan sebagainya). Contoh-contoh bentuk tanggung jawab yang dapat diberikan kepada anak sejak dini adalah:

1. Membiasakan anak menyelesakan tugas-tugas sekolahnya sendiri secara baik.

2. Memberikan tugas rumah kepada anak sesuai dengan usianya, misalnya meminta anak untuk selalu mengembalikan seluruh mainan pada tempat semula setelah usai bermain. Anak yang diberikan tugas tertentu akan berkembang rasa tanggung jawabnya.

3. Meminta anak untuk meminta maaf atas kesalahan yang telah diperbuat. Hal ini diyakini akan mampu mengasah kepribadian anak yang memiliki sifat mau mengakui kesalahannya.

4. Mengenalkan sanki secara wajar kepada anak atas kesalahan yang telah dilakukan sesuai dengan usainya, dII. Hal ini mengajarkan kepada anak bahwa setiap perbuatan yang telah dilakukan adalah memiliki konsekwensi yang harus ditanggung.

\section{Kerjasama}

Kerjasama diartikan sebagai sebuah usaha yang dilakukan bersama-sama untuk mewujudkan suatu tujuan yang sama. Melaksanakan tugas secara bersama-sama baik dengan 
saudara kandung nya atau dengan teman di lingkungannya adalah bentuk kerjasama yang bisa ditanamkan kepada anak baik di lingkungan rumah atau di lingkungan sekolah.

\section{Sederhana}

Sederhana diartikan sebagai sikap atau prilaku tidak berlebihan terhadap sesuatu benda dan lebih mementingkan manfaat dan tujuannya. Menunjukan sikap apa adanya, tidak memaksakan diri dengan melakukan upaya-upaya yang dilarang oleh norma untuk mengambil yang sesungguhnya bukan haknya, mengajak anak untuk rajin menabung dan menggunakan sesuai dengan keperluannya, anak yang terbiasa bersikap sederhana akan terwujud tidak akan mengambil kesempatan untuk berbuat curang, karena salah satu penyebab seseorang melakukan perbuatan korupsi adalah adanya kesempatan selain dari niat dan sifat serakahnya.

\section{Kerja keras}

Kerja keras dalam Kamus Besar Bahasa Indonesia diartikan usaha sungguh-sungguh untuk mencapai tujuan yang dilakukan secara terus-menerus, tidak mudah menyerah dalam menghadapi masalah atau tantangan. Contoh yang bisa diberikan di dalam rumah adalah dengan memberikan reward atas pencapain kerja keras yang telah dilakukan oleh anak dalam belajarnya. Hal ini dilakukan dalam rangka bahwa, untuk mencapai sesuatu dibutuhkan kerja keras dan kegigihan, sekaligus mengenalkan kepada anak untuk tidak mencapai sesuatu dengan cara instan. Sehingga kelak ketika anak ingin menjadi seorang yang kaya harus dengan bekerja keras untuk mendapatkan uang, bukan dengan mengambil uang yang bukan haknya.

\section{Berani}

Berani adalah adanya rasa percaya diri yang besar dalam menghadapi tantangan, tidak takut dalam menghadapi sesuatu yang diyakini kebenarannya. Contoh tauladan yang dapat diberikan kepada anak adalah orang tua berani mengingatkan orang lain yang membuang sampah tidak pada tempatnya, orang yang menyerobot antrian, orang yang merokok tidak pada tempatnya misalnya, yang mereka jumpai pada saat mereka berada baik didalam rumah maupun diluar rumah. Hal 
ini diyakini kelak anak akan meniru keberanian orang tua nya untuk mengingatkan siapa saja yang dijumpai dilingkungan sekitarnya ketika melakukan kesalahan. Sehingga diharapkan ketika di Sekolah anak akan memiliki keberanian untuk mengingatkan dan atau bahkan melaporkan kepada guru kelasnya ketika menjumpai ada temannya yang menyontek pada saat ujian. Sehingga kelak dewasa ketika menjumpai kecurangan yang terjadi baik dilingkungan pekerjaannya maupun dilingkungan diluar pekerjaannya dia akan memiliki keberanian untuk melaporkan juga kepada pihak yang berwajib.

\section{Adil}

Adil diartikan sebagai perilaku yang sama pada setiap orang, memperlakukan orang seperti hal nya kita ingin diperlakukan, tidak memihak, seimbang antara hak dan kewajiban. Contoh tauladan yang dapat dibiasakan dilingkungan sekolah jika orang tua ingin memberikan bingkisan atau oleh-oleh hendaknya diberikan kepada seluruh guru dan petugas sekolah yang ada dengan tanpa membeda-bedakan satu guru dengan guru yang lain. Tidak memberikan bingkisan dalam bentuk apapunhanya kepada wali kelas saja pada saat setelah menerima raport atau ujian, jika ingin memberikan kepada wali kelasnya, maka harus juga memberikan kepada seluruh elemen sekolah mulai dari kepala sekolah sampai dengan petugas kebersihan dan petugas keamanannya. Hal ini dimaksudkan untuk meminimalisir kesenjangan sosial karena sesungguhnya pemberian yang diberikan dengan adanya maksud dan tujuan tertentu adalah bentuk perilaku korupsi yang berupa Gratifikasi.

Korupsi merupakah evolusi dari perilaku koruptif, membiarkan perilaku koruptif dari hal-hal yang kecil sama hal nya dengan membiasakan perilaku koruptif terus dilakukan dan akan menjadi prilaku pidana korupsi. SEMAI menanamkan nilai-nilai yang mengandung norma sikap anti korupsi, korupsi terjadi disebabkan karena tiga hal, pertama karena "niat", yaitu sebuah tindakan yang telah direncanakan dengan baik dalam rangka untuk mensukseskan niat perbuatannya. Dalam hal melakukan korupsi tidak dilakukan secara tiba-tiba, namun perlu perencanaan secara matang dan sistematis. Kedua "kesempatan" yaitu perbuatan yang memanfaatkan aji mumpungnya untuk mengeruk keuntungan baik untuk dirinya sendiri atau untuk golongannya, selagi yang bersangkutan berada dalam posisi jabatan tertentu yang memungkinkan. Ketiga sifat "serakah", sifat ini pada hakikatnya bermula karena 
tidak dimilikinya sifat sederhana pada diri seseorang. Karena sesungguhnya serakah muncul karena adanya keinginan untuk lebih dari yang sudah ada dalam diri seseorang itu.

SEMAI diberikan dengan model pendidikan learning by modeling yang diterapkan baik di rumah maupun di sekolah, akan dapat membentuk pribadi anak yang memiliki nilai integritas diri yang tinggi pula, model pembelajaran dengan muatan nilai-nilai anti korupsi kepada anak bermanfaat untuk mewujudkan bangsa Indonesai yang anti korupsi dikemudian hari. Pendidikan anti korupsi kepada anak sejak usia dini akan dirasakan manfaatnya dan terlihat hasilnya kelak dan tentu ini adalah investasi masa depan yang sangat berharga, kelak anak akan menjadi pribadi yang yang memiliki nilai-nilai anti korupsi.

\section{Pendidikan Anti Korupsi Pada Anak Usia Dini}

Sastrapratedja (Kaswardi, 1993), mendefinisikan pendidikan nilai sebagai penanaman dan pengembangan nilai-nilai pada diri seseorang. Dalam pengertian yang hampir sama, Mardiatmadja (1986) mendefinisikan pendidikan nilai sebagai bantuan terhadap peserta didik agar menyadari dan mengalami nilai-nilai serta menempatkannya secara integral dalam keseluruhan hidupnya. Dalam National Resource Center for Value Education, pendidikan nilai didefiniskan sebagai usaha untuk membimbing peserta didik dalam memahami, mengalami, dan mengamalkan nilai-nilai ilmiah, kewarganegaraan dan sosial yang tidak secara khusus dipusatkan pada pandangan agama tertentu. Dari beberapa definisi di atas dapat ditarik sebuah definisi pendidikan nilai yang mencakup keseluruhan aspek, yaitu bahwa pendidikan nilai merupakan pengajaran atau bimbingan kepada peserta didik agar menyadari nilai kebenaran, kebaikan, dan keindahan, melalui proses pertimbangan nilai yang tepat dan pembiasaan yang konsisten.

Sedangkan tujuan pendidikan nilai sebagaimana dilaporkan dalam hasil peneltiian Hidayati (2008), secara umum dikemukakan Komite APEID (Asia and the Pasific Programme of Educational Innovation for Development), bahwa pendidikan nilai ditujukan untuk: (a) menerapkan pembentukan nilai kepada anak; (b)menghasilkan sikap yang mencerminkan nilai-nilai yang diinginkan; dan (c) membimbing perilaku yang konsisten dengan nilai-nilai tersebut. Dengan demikian, pendidikan nilai memiliki tujuan meliputi tindakan mendidik yang berlangsung 
mulai dari usaha penyadaran nilai sampai pada perwujudan perilaku-perilaku yang bernilai (UNESCO, 1994).

Mulyana (2004: 43) mengatakan bahwa terdapat beberapa pendekatan yang dapat diambil dalam implementasi pendidikan nilai, di antaranya adalah: vocation, dimana peserta didik diberi kesempatan dan keleluasaan untuk bebas mengekspresikan respon afektualnya; inculcation, dimana peserta didik digiring secara sugestif; moral reasoning, dimana terjadi transaksi intelektual dalam mencari pemecahan masalah; value clarification, dimana upaya dilakukan melalui stimulus pola pengajaran yang terarah; value analysis, dimana siswa didorong untuk melakukan analisis moral; moral awareness, dimana siswa dibangkitkan secara sengaja, kesadarannya akan nilai moral tertentu melalui stimulus tertentu; commitment approah, dimana dalam pendekatan ini sejak awal dan dengan diberitahukan kepada mereka suatu pola pikir dan penilaian selama proses ini berlangsung; serta union approach, dimana peserta didik dibawa melakoni secara langsung peran-peran nilai dalam kehidupan sehari-hari.

Selain beberapa pendekatan yang dapat digunakan dalam proses implementasi pendidikan nilai di atas, terdapat juga beberapa pendekatan yang disampaikan oleh Koesoema A (2007), yang menyebutkan bahwa terdapat lima metodologi yang dapat dilakukan dalam menanamkan nilai-nilai kepada peserta didik. Pertama adalah dengan cara "mengajarkan". Untuk dapat melakukan sesuatu yang baik, yang adil, yang bernilai, kita harus terlebih dahulu mengetahui dengan jernih apa yang dimaksud dengan kebaikan, keadilan, dan nilai. Pendidikan karakter, yang oleh Koesoema disebut banyak berurusan dengan penanaman nilai, mengandaikan pengetahuan teoritis tentang konsep-konsep nilai tertentu. Kedua adalah keteladanan. Anak lebih banyak belajar dari apa yang mereka lihat. Dalam konsep psikologi, ini disebut dengan modelling. Oleh karenanya, secara tidak langsung, pendidikan nilai merupakan tuntutan kepada pendidik untuk senantiasa menjadi model yang tepat bagi peserta didik.

Ketiga adalah menentukan prioritas. Maksudnya adalah menentukan nilai-nilai yang dianggap penting untuk diimplementasikan dalam sebuah sekolah tertentu. Oleh karenanya, lembaga pendidikan harus terlebih dahulu menentukan tuntutan standar atas ragam nilai yanga kan ditawarkan. Keempat adalah praksis prioritas. Hal ini berkenaan dengan visi dan misi lembaga pendidikan terkait yang ingin 
menanamkan nilai-nilai tertentu kepada peserta didiknya. Dan kelima adalah refleksi, yaitu melihat dengan sadar sejauhmana pendidikan nilai telah tercapai.

Adapun tujuan pendidikan anti korupsi pada anak usia dini sebagaimana diamanahkan oleh Komisi Pemberantasan Korupsi (KPK) secara umum adalah sebagai berikut:

1. Anak memahami dengan baik perilaku anti koruptif.

2. Anak memiliki perilaku sikap anti korupsi.

3. Memberikan bekal kepada anak agar kelak tidak melakukan perbuatan korupsi karena sesungguhunya perbuatan korupsi selain merugikan orang lain juga mencelakakan bagi pelakunya sendiri.

4. Bagian dari ikhtiar orang tua untuk menghentikan "produksi" koruptor sejak dari rumah.

5. Mencetak generasi bangsa yang memiliki integritas diri yang tinggi.

6. Melakukan pencegahan perilaku korupsi sejak dini.

Tujuan-tujuan penanaman nilai-nilai di atas diusung oleh Komisi Pemberantasan Korupsi (KPK) melalui programprogram yang dicanangkannya yang menyebar ke banyak lembaga dan instansi pendidikan formal maupun non formal di seluruh Indonesia. Metode-metode dan pendekatan pembelajaran yang biasa digunakan dalam pendidikan anak usia dini, secara kreatif dikemas oleh Komisi Pemberantasan Korupsi (KPK) ke dalam bentuk-bentuk upaya penanaman SEMAI. Melalui banyak pendekatan seperti permainan, outbond, seminar, pelatihan, character building, dll. KPK mencoba mengambil peran tidak hanya dalam bentuk pemberantasan korupsi secara langsung, melainkan juga mengambil peran preventif yaitu dengan cara meminimalisir bibit-bibit tumbuhnya sifat koruptif dengan pendidikan nilai-nilai anti korupsi yang dapat ditanamkan sejak dini. Secara lebih lanjut, kemasan permainan khas anak usia dini, dalam kaitannya dengan penanaman SEMAl, akan ditulis dalam pembahasan artikel selanjutnya.

\section{SIMPULAN}

Hitam putih anak itu tergantung pada bagaimana orang tua memberikan ukiran pada anak tersebut. Ukiran tersebut dimaksudkan sebagai pembangunan karakter. Dalam membangun generasi anti korupsi saat ini haruslah di mulai 
dengan membangun karakter sejak usia sedini mungkin. Membangun karakter (character building) adalah proses yang dilakukan secara terus menerus sampai pada terbentuknya pribadi manusia yang memiliki prinsip yang kuat. Sehingga jika di tempa situasi bagaimanapun tetap akan menjadi pribadi yang kuat memegang prinsip, dan lingkungan akan mengenal dirinya sebagai pribadi yang berintegritas.

Agar pembelajaran dalam pengenalan prilaku anti korupsi dapat tercapai secara maksimal tidak hanya memberikan dengan modelceramah saja, anak lebih mudah merekam dengan apa yang telah di lihat dan mencontoh apa yang dilakukan oleh orang terdekatnya. Pemberantasan korupsi biarlah menjadi wilayah kerja para aparat penegak hukum, peran pencegahan prilaku korupsi menjadi wilayah setiap individu, karena sesungguhnya yang paling penting dalam menyelesaikan persoalan korupsi adalah dengan cara melakukan pencegahan yang dimulai dari diri sendiri, mengajak orang terdekat (keluarga), kemudian lingkungan sekitar.

\section{REFERENSI}

Amin, Ahmad. 1988. Etika (IImu Akhlak). Jakarta: PT Bulan Bintang

Azwar, Saifuddin (2005). Sikap Manusia: Teori dan Pengukurannya. Yogyakarta. Pustaka Pelajar.

Desmita (2012). Psikologi Perkembangan Peserta didik. Bandung. Rosda Karya.

Hasanah, Uswatun (2010). Pendidikan Nilai untuk anak usia dini http://pauduny.blogspot.co.id/2010/10/pendidikan-nilai-untukanak-usia-dini.html. 24 November 2017

Hidayati, Laily (2008). Transinternalisasi Nilai: Implementasi Pendidikan Nilai di SDN Krebet I Jambon Ponorogo. Skripsi Jurusan Psikologi. UIN Malang.

http://webpintar.blogspot.co.id/2009/05/6-langkah- melatihanak-berani-dan.html. 24 November 2017

Kaswardi EM. (1993). Pendidikan Nilai Memasuki Tahun 2000. Jakarta. Grasindo. 
Kesuma, Dharma, Cepi Triatna dan Johan Permana (2012). Pendidikan Karakter Kajian Teori dan Praktek di Sekolah. Bandung. Rosda

Koesoema. Doni. (2007). Pendidikan Karakter. Jakarta. Grasindo.

Komisi Pemberantasan Korupsi (2014). Mengenal gerakan Sya Perempuan Anti Korupsi. https://acch.kpk.go.id/id/ragam/saya-perempuanantikorupsi/mengenal-gerakan-saya-perempuan-antikorupsi-spak, 20 September 2017

Lickona, Thomas (2016). Persoalan Karakter. Jakarta. Bumi Aksara.

Lockona, Thomas (2016). Mendidik untuk Membentu Karakter.Jakarta. Bumi Aksara

Mulyana R. (2004). Mengartikulasikan Pendidikan Nilai. Alfabeta. Bandung.

Nasional Pendidikan. Jakarta. Departemen Pendidikan Nasional

Rosikah, darul Chatrina dan Desi Marliani Listianingsih. Pendidikan Anti Korupsi kajian anti korupsi teori dan praktek (2016). Jakarta. Sinar Grafika

Susanto, Ahmad (2017). Pendidikan Anak Usia Dini (konsep dan teori). Jakarta. Bumi Aksoro

Suyanto (2010). Pendidikan Karakter Teori dan Implementasi. Jakarta. Rineka Cipta

Suyanto, Slamet (2012). Pendidikan Karakter untuk Anak Usia Dini .https://scholar.google.co.id/citations?user =p2gKX4AAAAJ\&hl=id. 8 November 2017

UU No. 20 Tahun 2003, tentang Sistem Pendidikan Nasional dan UU No. 14 Tahun 2005 tentang Guru dan Dosen. Jakarta. Visimedia.

UU No. 31 Tahun 1999 Jo UU No. 20 Tahun 2001 tentang Tindak Pidana Pemberantasan Korupsi 
FIRA MUBAYYINAH

238 | AL HIKMAH: INDONESIAN JOURNAL OF EARLY CHILDHOOD ISLAMIC EDUCATION | VOL.1 (2), 2017 